\title{
The Effect of Pesantren-Based Metaphor on Self-Esteem of Santri
}

\author{
Diniy Hidayatur Rahman \\ Guidance and Counseling Department, Universitas Negeri Malang \\ Malang, East Java, Indonesia \\ Corresponding e-mail: diniy.hidayatur.fip@um.ac.id
}

\begin{abstract}
The study examined the effect of pesantren (Indonesian Islamic boarding house)-based metaphor on selfesteem of santri (students of pesantren). 11 subjects with low self-esteem participated in the study. Five of them served as participants in the experimental group while the rests participated in the control group. The Self-Esteem Scale (SEC) developed by Rahman (2013) was used to measure their self-esteem. As the study used nonequivalent (pre-test and post-test) control-group design, subjects in the experimental group received pesantren-based metaphor, while who in the control group received no intervention. The Wilcoxon Matchedpairs Signed-ranks Test was applied to compare the scores of the two groups. Results show score differences (Asymp. Sig. $=0,043$ ) between the two, in which the score of the experimental group tended to rise while the control group score was likely to remain. The results are then discussed within the framework of the advantages of pesantren-based metaphor.
\end{abstract}

Keywords: $\quad$ metaphor; self-esteem; pesantren

\section{INTRODUCTION}

Identity issues are a major concern of adolescence. Questions such as who am I, what should I be, and other questions that focus on the self, are the hallmark of adolescence seeking his/her identity (Finkenauer, Engels, Meeus \& Oosterwegel, 2002:25). In searching for the identity, adolescence often compares him/herself to the ideal figure. When he/she views him/herself as idealized, he will respect the self positively, that means he has high self-esteem. Conversely, when he/she regards him/herself as far from the ideal, he/she will view the self negatively (low self-esteem).

Self-esteem is a global evaluative dimension of the self (Santrock, 2011: 315). Adolescent usually judges him/herself globally so he/she will obtain a clear picture of the self, and then compares it to his/her ideal criteria. The concept of self-esteem is closely related to three other concepts that are inseparable, namely: self-concept, self-image, and ideal self (Lawrence, 2006: 3). Selfconcept is a broad term that covers self-image, ideal self, and self-esteem. According to Lawrence (2006: 2-5), self-concept is the overall mental and physical characteristics of an individual, along with his/her judgment about them. Self-image is an individual's understanding about his/her mental and physical characteristics, while ideal-self is a set of circumstances that he/she considers as ideal standards. A comparison he/she makes between his/her self-image and his/her idealself is then referred as self-esteem.

Coopersmith (1967: 13) states that selfesteem has three levels: high, medium, and low. People who have high self-esteem will see themselves as competent and meaningful. Conversely, if they have low self-esteem, they will see themselves as worthless and hopeless that will further affect their behavior negatively (Mruk, 2006: 153). According to Coopersmith (1967), people with high selfesteem will always appear to be active, expressive, confident in expressing opinions, having high social interest, believing in themselves, and optimistic in facing problems. On the contrary, people with low self-esteem will appear to be passive, depressive, pessimistic in facing troubles, and dependent on others.

Unfortunately, according to Finkenauer, Engels, Meeus \& Oosterwegel (2002: 37), this process of identity seeking by adolescent is often characterized by unrealistic views, which negatively affect his/her social, psychological, and emotional life. Some research shows that adolescence's esteem tends to decrease in this period that is accompanied by substantial deterioration in his/her academic and achievement motivation (Baldwin \& Hoffman, 2002). Furthermore, Robins \& Trzesniewski (2005) found that this 
degradation is mainly caused by body image and other puberty problems.

Many studies in educational setting show that self-esteem is closely related to academic performance, social adjustment, and intensity of unlawful acts. Research conducted by Puspitasari (2007) found that self-esteem has positive correlation with academic achievement of high school students; the lower their self-esteem, the lower their academic achievement. Other research also showed that self-esteem has positive correlation with social adjustment (Syahbita, 2009). It means that students with low selfesteem tend to have low social adjustment, and vice versa. Furthermore, it was also found that low self-esteem increased the intensity of aggression behavior (Utami, 2009), narcotics abuse (Adhi, 2008), as well as premarital sexual behavior of students (Arista, 2006). Research conducted by Overholser, et al. (In Plummer, 2005: 16) also found that low selfesteem in adolescents is closely related to high levels of depression, desperation, and suicidal ideas. Based on the studies, it can be concluded that low self-esteem is correlated to adolescence problematic behaviors. If this problem of esteem is not immediately intervened, it may be widespread in more worrying circumstances and behavior. The results of such research indicate the importance of providing intervention to increase this self-esteem. Therefore, counselors at school need to take preventive and curative action to deal with these low selfesteem issues.

One of techniques that can be used to increase self-esteem in counseling setting is metaphor. Lexically, the word "metaphor" comes from the Greek "metapherin" which means transferring or bringing something to another place (Burns, 2007: 4). Furthermore, Kopp (1998) defines metaphor as a language style in which one thing is expressed in another term that gives a more lively impression. In counseling and psychotherapy, the variants of metaphor used commonly for therapeutic purposes are figurative words, images, films, analogies, and anecdotes. However, the definition of metaphor has been lately expanded to include not only language styles but also experiences, games, and family processes (Chesley, Gillet \& Wagner, 2008).

The use of metaphors in counseling will provide many benefits not obtained with other techniques. According to Burns (2007: 4-7) there are eight benefits in using metaphor as counseling technique: (1) metaphor is interactive; (2) metaphor attracts counselee's attention; (3) metaphor can overcome counselee's resistance; (4) metaphor stimulates counselee's imagination; (5) metaphor encourages the search of meaning; (6) metaphor can develop problem solving skills; (7) metaphor may bring about new possibilities; and (8) metaphor stimulates independent decision-making. Lyddon, Clay $\&$ Sparks (2001) also add that the use of metaphor in counseling can be useful for: (1) building relationships with counselees; (2) accessing and symbolizing emotions; (3) uncovering and challenging the counselee's unspoken assumptions; (4) overcoming counselee's resistance; and (5) introducing a new viewpoint.

Several case studies have been conducted by prominent psychotherapists to prove the effectiveness of metaphor in enhancing selfesteem. Kopp (2007: 30-43) proved that client-generated metaphor can increase selfesteem of a subject who experienced Major Depressive Disorder. Smit (2007: 89-99) also used Therapist-Generated Metaphor to increase self-esteem of his client who experienced abusive relationship. Another study conducted by Powell, Newgent \& Lee (2006) also found that cinema therapy, a form of metaphor, can significantly increase selfesteem of adolescents who experience severe emotional disturbance. This research showed that the increase is permanent, that is known after a week follow-up. Similar research using bibliotherapy, as another form of metaphor, was also applied by Horton (1996) to improve self-esteem of elementary school students. The results showed that bibliotherapy can increase their self-esteem significantly.

Pesantren (Islamic boarding house) is a very unique educational institution in Indonesia. The students, known as santri, stay in the dormitory for 24 hours to study Islam under the guidance of religion teachers, known as kiai (grand master) and ustadz (teacher). In pesantren, metaphors in story format that contain wisdom teachings are something familiar. Those stories can be found abundantly in kitab kuning, the books written by ancient religious scholars containing Islamic teachings and often discussed by the santri. Kiai and ustadz sometimes tell similar stories to improve santri's learning motivation and to correct their behavior. One of the kitab kuning is Qishashul Anbiya by Ibnu Katsir which contains stories of the wise prophets and messengers of Allah. Some other kitab kuning 
are al-Mawaa'idh al-'Ushfunriyyah by $\mathrm{Abu}$ Bakr Al-'Ushfuriy and Durratun Naashihiin by Ahmad As-Shakir Al -Khubawiy which tell the story of the salafusshalih (some pious ancestors). Those kinds of books are one of the uniqueness of pesantren, where kyai, ustadz, and santri read them every day with a strong belief about the truth of their contents (Rahman, 2010). Therefore, the use of these stories to intervene in self-esteem issues has another advantage: the santri are more likely to accept them without rejection because they have strong belief about the truth of the stories. Based on the above explanation, the purpose of this research is to examine the effect of pesantren-based metaphor on selfesteem of santri.

\section{METHOD}

This study used a nonequivalent (pre-test and post-test) control-group design. The main characteristics of this design are: (1) there are two groups in the study: the experimental and the control group; (2) only the experimental group will be intervened while the control group is left without any intervention; (3) subjects obtained by purposive sampling; and (4) before and after each intervention, subjects' self-esteem in both groups will be measured (Creswell, 2009: 160).

The selection of subjects was done based on the fulfillment of the following criteria: (1) recorded as students of a pesantren who are on senior high school; (2) identified as low esteemed students based on measurement with Self-Esteem Scale (SES) by Rahman (2013); (3) identified as low esteemed students based on a depth interview and teacher's recommendation; (4) have average level of IQ or above; and (5) are willing to follow the entire research process.

Those inclusion criteria set five students as members of the experimental group and the other six as members of the control group. The experimental group was then intervened with pesantren-based metaphor while the control group was left without any intervention. The counseling process for the experimental group consisted of five sessions held over five weeks. The five meetings were the elaboration of five general phases of counseling proposed by Ivey, Ivey \& Zalaquett (2010: 19-20), which consist of: (1) relationship building; (2) story and strength exploration; (3) goal setting; (4) restorying; and (5) action. At the restorying stage, three metaphorical tales are used to promote change: (1) Uwais Al-Qarni: Underrated by Earth Population but Glorified by the Celestial Residents; (2) The story of Ibn Hajar, The Son of Stone; and (3) With 40 Years of Sinning, Pray is Accepted. Before and after the intervention, subjects' esteem was measured by the Self-Esteem Scale developed by Rahman (2013) based on the construct of self-esteem by Coopersmith (1967). Similar measurements were also made on subjects in the control group.

To analyze the data, this study used The Wilcoxon Matched-pairs Signed-ranks Test. The decision about the effect of metaphor on self-esteem will be taken using two criteria: (1) when the value of Asymp. Sig. (2-tailed) is smaller than or equal to 0.05 , it can be decided that the intervention can increase self-esteem; (2) when the value of Asymp. Sig. (2-tailed) is greater than 0.05 , it can be decided that the intervention cannot increase the self-esteem. Furthermore, in relation to the application of the control-group nonequivalent (pre-test and post-test) design in this study, conclusion will be taken with the following conditions.

1. If the difference between the pretest and posttest scores in both groups is equally significant, it can be concluded that the change in the experimental group is not caused by the independent variable $(\mathrm{X})$. In other words, the effect of pesantren-based metaphor on self-esteem is very doubtful.

2. If the difference between pretest and posttest scores in the experimental group is significant, whereas the difference between the pretest and posttest scores in the control group is not, it can be concluded that the change is caused by the independent variable. In other words, the pesantren-based metaphor has an effect to increase the self-esteem.

3. If the difference between the pretest and posttest scores in the control group is significant, whereas the difference between pretest and posttest scores in the experimental group is not, it can be concluded that the pesantren-based metaphor has no effect to increase the selfesteem.

\section{RESULTS}

\subsection{Subjects Selection}

As mentioned earlier, subject selection in this study was conducted through five stages in order to obtain subjects perfectly suited to 
the purpose of the study. Here are the processes and results of the selection.

1. The first stage was identifying the subjects listed as santri (students) of Islamic boarding house who were in senior high school. At this stage, 241 santri met the criteria.

2. The second stage was identifying the subjects with low self esteem. This was done by administering Self-Esteem Scale (SES). Students with low and very low SES score were included in the stage. The score set as early indicator that the subjects' esteem were low. At this stage, 13 santri met the criteria.

3. The third stage was the follow-up identification based on depth interview and teacher's recommendation. The inclusion of subjects was specifically based on the fulfillment of several of the low self-esteem characteristics, such as: inferiority, withdrawal, underachievement, dependency on others, passivity, and/or antisocial behavior. At this stage, 13 santri met the criteria.

4. The fourth stage was done by measuring IQ of 13 subjects. Subjects' IQ must be at average level or above. At this stage, 13 santri also met the criteria.

5. The last stage was asking subjects willingness to participate in the research. Among 13 santri, two of them refused to participate for reasons not explained in detail.

Based on the stages, eleven subjects were included in the study, four of which were men and seven were women. Through a draw, five santri were assigned as members of the experimental group and the other six as members of the control group. A more detailed description of the eleven subjects can be seen in table 1 .

\subsection{Description of Research Data}

Prior to the intervention, 11 subjects were asked to fill out the SES. Their selfesteem scores is presented in table 1. To ensure that there was no significant difference in self-esteem scores between the experimental and control groups at pretest, the Mann-Withney U statistical test was applied. The absence of the difference is a prerequisite for research with a nonequivalent (pre-test and post-test) control-group design. The test obtained $Z=-0.457$ and Asymp Sig. (2-tailed)
$=0.647$. Based on the test result, it can be concluded that there was no significant difference between the experimental and the control group in the pretest, so the intervention can be proceed.

Interventions to the experimental group were held in five meetings over five weeks. The intervention was given by the researcher himself who acted as a counselor. The posttest then was administered to the subjects to determine their self-esteem level after receiving the entire intervention process. The same SES was also given to members of the control group. In detail, the experimental group SES scores are presented in table 2 and the control group scores in table 3 . In table 2 , it can be seen that the posttest scores of all experimental subjects were higher than their pretest score with significant gain (75.4). However, in term of self-esteem classification, there was still a subject (AL) with low selfesteem.

Table 1. Scores and Self-Esteem Classification of Subjects

\begin{tabular}{cccccc}
\hline No. & $\begin{array}{c}\text { Initial } \\
\text { Name }\end{array}$ & Sex & $\begin{array}{c}\text { Esteem } \\
\text { Scores }\end{array}$ & $\begin{array}{c}\text { Esteem } \\
\text { Class }\end{array}$ & $\begin{array}{c}\text { Research } \\
\text { Group }\end{array}$ \\
\hline 1. & MAY & M & 139 & L & Experiment \\
\hline 2. & AR & M & 146 & L & Experiment \\
\hline 3. & HS & F & 149 & L & Experiment \\
\hline 4. & AL & F & 125 & VL & Experiment \\
\hline 5. & K & F & 127 & VL & Experiment \\
\hline 6. & FI & M & 152 & L & Control \\
\hline 7. & MIS & M & 156 & L & Control \\
\hline 8. & S & F & 123 & VL & Control \\
\hline 9. & RA & F & 128 & VL & Control \\
\hline 10. & DFS & F & 150 & L & Control \\
\hline 11. & SNA & F & 125 & VL & Control \\
\hline & & & a. M=Male; F=Female, L=Low, VL=Very Low
\end{tabular}

In the control group (table 3), the posttest score of four subjects increased, one subject was unchanged, and the other one decreased. The average gain obtained was also unsignificant. In term of self-esteem classification, the four subjects were low and the other two were very low. Among the six, only RA that changed from very low to low, while the others did not. 
Table 2. Pretest and Posttest Scores Of Members of Experimental Group

\begin{tabular}{|c|c|c|c|c|c|}
\hline \multirow{2}{*}{$\begin{array}{l}\text { Initial } \\
\text { Name }\end{array}$} & \multicolumn{2}{|c|}{ Pretest } & \multicolumn{2}{|c|}{ Posttest } & \multirow{2}{*}{ Gain } \\
\hline & Score & Class & Score & Class & \\
\hline MAY & 139 & $\mathrm{~L}$ & 231 & $\mathrm{H}$ & 92 \\
\hline $\mathrm{AR}$ & 146 & $\mathrm{~L}$ & 240 & $\mathrm{H}$ & 94 \\
\hline $\mathrm{HS}$ & 149 & $\mathrm{~L}$ & 215 & $\mathrm{H}$ & 66 \\
\hline $\mathrm{AL}$ & 125 & VL & 183 & $\mathrm{~L}$ & 58 \\
\hline $\mathrm{K}$ & 127 & VL & 194 & $\mathrm{H}$ & 67 \\
\hline Mean & \multicolumn{2}{|c|}{137,2} & \multicolumn{2}{|c|}{212,6} & 75.4 \\
\hline
\end{tabular}

Table 3. Pretest and Posttest Scores Of Members of Control Group

\begin{tabular}{|c|c|c|c|c|c|}
\hline \multirow{2}{*}{$\begin{array}{l}\text { Initial } \\
\text { Name }\end{array}$} & \multicolumn{2}{|c|}{ Pretest } & \multicolumn{2}{|c|}{ Posttest } & \multirow{2}{*}{ Gain } \\
\hline & Score & Class & Score & Class & \\
\hline FI & 152 & $\mathrm{~L}$ & 158 & $\mathrm{~L}$ & 6 \\
\hline MIS & 156 & $\mathrm{~L}$ & 152 & $\mathrm{~L}$ & -4 \\
\hline $\mathrm{S}$ & 123 & $\mathrm{VL}$ & 128 & VL & 5 \\
\hline RA & 128 & VL & 133 & $\mathrm{~L}$ & 5 \\
\hline DFS & 150 & $\mathrm{~L}$ & 158 & $\mathrm{~L}$ & 8 \\
\hline Mean & \multicolumn{2}{|c|}{139} & \multicolumn{2}{|c|}{142,17} & 3.33 \\
\hline
\end{tabular}

\subsection{Hypothesis Testing}

As mentioned earlier, hypothesis testing in this study was conducted by comparing the pretest and posttest scores in both groups. The results of the analysis using the Wilcoxon in the experimental group obtained Asymp Sig. (2-tailed $)=0.043$. Based on the value, it can be concluded that significant increase happened after the intervention. On the other hand, The control group obtained Asymp. Sig. (2tailed $)=0.078$, which means that no significant increase after the intervention.

Based on the above analysis, it can be summarized that: (1) in the experimental group, there was a significant scores increase in post-test compared to pre-test; (2) in the control group, there was no significant score difference between pre-test and post-test. Therefore, based on the criteria of hypothesis rejection mentioned earlier, it can be concluded that the hypothesis is accepted. In other words, the pesantren-based metaphor is effective in increasing the self-esteem of the santri.

\section{DISCUSSION}

Self-esteem is a comparison between individual's self-image and ideal self (Lawrence, 2006: 2-5). Furthermore, low self esteem is a condition in which the individual considers him/herself worthless because he/she find a considerable gap between his/her ideal self and self-image. Such gap can occur for two reasons: unrealistic self-image and unrealistic ideal self. These two conditions are rooted in the mistake of thinking which then result in the mistake of feeling and behaving.

To overcome the problem, the main thing to do is evaluating the unrealistic way of thinking. The use of common directive questions in counseling will make counselee's analytical mind-set active (Conte, 2009: 65). In this condition, to make the counselee realize about his/her unrealistic thoughts will be more difficult. This is because the counselor will deal with the counselee's point of view that has been formed through experiences throughout his/her life. It will take a long time and a big effort to make the counselee change his/her earlier viewpoint with another one. Moreover, if the counselor is less skilled in asking evaluative questions, the counselee will impress that he/she is being judged so he/she will be resistant to the counseling.

The metaphor, with all its advantages, can facilitate the evaluation process of counselee's thinking more effectively. Metaphor in the form of story can encourage the counselee to evaluate his/her way of thinking nondirectively. According to Conte (2009: 65), the counselee will be more open in accepting new ideas when his mind is in a metaphoric mode rather than in analytical mode. When presented a story about a character, the counselee will listen it nondefensively. This is because the story is something exciting to hear and it can give an emphasis to certain thing (i.e. self-esteem) that is the concern of the counselee without touching it directly. When hearing a story, he/she will run into a psychological condition called narrative transport. This condition occurs when the emotion of the counselee is tied to the emotion of the character(s) in the story. In this condition, the counselee will not only be interested in the contents of the story, but he will also follow the emotional journey of the character as if he went through the story himself. This is where self-evaluation will automatically occur within the counselee. $\mathrm{He} / \mathrm{she}$ will compare him/herself to the character, especially in evaluating his/her way of self-imaging and making ideal self. If the story contains lessons related to the unrealistic self-image and ideal self, he will change his/her viewpoint through the inspiration he/she gets from the metaphorical story. 
The metaphorical stories mentioned above are found in many kitab kuning (Islamic classic book) studied in pesantren. These books, for example, are Qishashul Anbiya' by Ibnu Katsir which contains stories about the Prophets and Messengers of Allah, alMawaa'idh al-'Ushfuuriyyah by Abu Bakr Al'Ushfuriy, and Durratun Naashihiin by Ahmad As-Syakir Al -Khubawiy that tell the story about the wisdom of Islamic ancestors. The stories in the books are widely known by the santri and they have a strong belief in the truth of them. Using such stories, the intervention to increase self-esteem will be more successful. This is in line with Ellis's statement (in Seligman, 2006: 314-315) that a counselee's belief in something can be used to change his/her irrational thoughts more effectively.

Furthermore, when the counselee realizes that his/her way of thinking about him/herself is unrealistic, he/she can be encouraged to plan new effective behaviors. For this purpose, the metaphorical story usually provides new possible adaptive behaviors that the counselee can do A good story usually begins with a problem faced by the main character and then ends with solving it. In solving the problem, the character usually performs certain actions. These actions can be a reference for the counselee to develop action plans that can strengthen his sense of esteem.

\subsection{Subjects' Esteem before Intervention}

Before intervention, the self-esteem of subjects was measured with SES. Of 241 santri, seven of them were classified as having low self-esteem and the other six were classified as having very low self-esteem. 11 students met the criteria and set as subjects of the research.

According to their development stage, the santri are in adolescence phase. At this time, their primary focus is on seeking identity. Questions such as who am I, what should I be, and other questions that focus on the self, are the hallmark of adolescence seeking his/her identity (Finkenauer, et. al., 2002: 25). In searching for the identity, adolescence often compares him/herself to the ideal figure. When he/she views him/herself as idealized, he will respect the self positively, that means he has high self-esteem. Conversely, when he/she regards him/herself as far from the ideal, he/she will view the self negatively (low self-esteem) (Mruk, 2006: 153).

A number of longitudinal studies have found a tendency of self-esteem decrease as the individual begins to be adolescent and a tendency of its increase as he/she begins to be adult (Baldwin \& Hoffman, 2002). Such a situation can be explained logically from the pattern of adolescent development. Adolescent has an imaginary audience (Arnett, 2009: 167). With this audience, he/she imagines that everyone is always watching what he/she looks like, what he/she says, and what he/she does, which makes him/her worry that others will judge him/her as an un-ideal person. In line with this imagination, he/she begin to change his/her main orientation from parents or family at home to his/her peers. Unfortunately, his/her peers are also beginning to have cognitive capacity to mock something they find strange and odd. Thus, the combination of the ability to self-evaluate, peer orientation, imaginary audience, and peers who tend to mock contributes greatly to lower his/her the selfesteem.

The logical explanation of the cause of self-esteem decrease presented by Arnett (2009: 167) above was proven empirically in this study. Of 11 subjects, eight of them showed low self-esteem due to body image issues and negative ratings given by peers. Subjects AR and MIS experience self-esteem problems due to negative judgments and treatment provided by their friends and teachers. The subject AL, DFS, S, RA, K and SNA value themselves negatively because of body image problem. As for the other three subjects, FI, HS and MAY experience selfesteem problems because they perceive themselves as weak academically. These subjects then express their low self-esteem into diverse behaviors, such as withdrawing from their friends, being reluctant to appear in public, and often seen to be lonely.

There are four aspects in which the individual commonly assesses and respects him/herself based on them: significance, power, competence, and virtue (Coopersmith, 1967: 40). Significance is defined as the presence of care, attention and affection received by individuals from their environment. Power is the individual ability to regulate his own behavior and influence the behavior of others. Competence is characterized by individual performance in performing various tasks well in accordance with age level and developmental tasks. 
Virtue is characterized by individual adherence to moral standards, ethics, and religious principles.

Based on the results of the SES, most of subjects in this study are low in three of four aspects mentioned above. However, there is usually only one or two aspects that are most concerned and contribute mostly in lowering their self-esteem (Coopersmith, 1967: 42). 9 Subjects (FI, HS, MAY, AL, DFS, S, RA, K and SNA) are low in self-esteem mainly due to competence factors, which are academically inadequate feelings and physical discomfort. As for the subject of AR and MIS, their selfesteem is low mainly because of the significance factor, which is the perception that friends and teachers judge and treat them negatively.

In addition to the eleven subjects, there may still be other santri with low self-esteem that are not identified by SES. This is because SES only measures global self-esteem, based on high or low score in the four sources of self-esteem mentioned above. In fact, Coopersmith (1967: 42) states that individual self-esteem is not determined solely by the high score in the four sources of self-esteem; it is more determined by the criteria used by the individual in assessing him/herself. In other words, it is possible that one earns a high total SES score, but he/she scores low in one aspect that is very meaningful to him/her. In that way, he/she is actually low in selfesteem, but can not be identified by SES.

\subsection{Subjects' Esteem after Intervention}

After intervention, it was found that subjects' self-esteem in the experimental group improved significantly and tended to remain unchanged in the control group. These are indicated by the results of $\backslash$ Wilcoxon Sign Rank Test that obtained Asymp Sig. (2-tailed) $=0.043$ in the experimental group and 0.078 in the control group. Thus, the pesantrenbased metaphor has an effect on increasing the self-esteem of santri. This increase in the experimental group is the effect of the intervention. This is evidenced by the absence of similar increase in subjects' self-esteem in the control group who did not receive any treatment.

Metaphorical story has the advantage to rapidly change the counselee's viewpoint that will further change his/her behavior (Burns, 2005: 11-12). He/she will be more open in accepting new ideas when his mind is in a metaphoric mode than when it is in an analytical mode. When presented a story about a certain character, he/she will listen to it without resistance. This is because the story is something exciting to hear and it can give an emphasis to certain thing (i.e. self-esteem) that is the concern of him/her without touching it directly. When reading a story, especially that he/she believe to be true, there will be a psychological condition called narrative transport. This condition occurs when the counselee's emotions is tied to the character's emotion in the story. In this case, he/she will not only be interested in the content of the story, but will also follow the emotional journey of the character as if he/she went through the story him/herself (Conte, 2009: 65). If the story has lessons to learn, he/she will be more empowered and more motivated by the experience of the character(s) in the story. This condition is, for example, shown by subject MAY after reading and discussing The Story of Ibn Hajar, The Son of Stone. He said: "Harusnya memang kita wajib belajar keras. Nggak ada yang nggak bisa kalau belajar terus. Wong batu aja hancur kena air. Masa orang nggak bisa... Sebodoh-bodohnya orang, pasti bisa pinter juga kalau belajar terus". (We should study hard. No fool if we keep learning. Stone can be destroyed by water. The same thing can happen to humans... Stupid people can also be clever if he/she continue to learn).

Rapid and efficient change by metaphor intervention mentioned above has been proven by Burns (2005: 11-13), a leading Australian psychotherapist. He used metaphor to help a child who was elective mute. Unable to communicate, Burns made no attempt to invite the child to speak; He only interviewed her mother and told a story while the child drew something next to them. Burns told a story of a friend in his childhood who also experienced an elective mute and can finally speak because of an event. Unexpectedly, the child dared to speak as soon as the story was delivered. This case study shows that metaphor can provide rapid change since the first session.

What occurred in the experimental group in this research is in line with many previous studies. Kopp (2007: 30-43) proved that client-generated metaphor can increase selfesteem of a subject who experienced Major Depressive Disorder. Smit (2007: 89-99) also used Therapist-Generated Metaphor to increase self-esteem of his client who 
experienced abusive relationship. Another study conducted by Powell, Newgent \& Lee (2006) also found that cinema therapy, a form of metaphor, can significantly increase selfesteem of adolescents who experience severe emotional disturbance. This research showed that the increase is permanent, that is known after a week follow-up. Similar research using bibliotherapy, as another form of metaphor, was also applied by Horton (1996) to improve self-esteem of elementary school students. The results showed that bibliotherapy can increase their self-esteem significantly. Rahman (2013) also proved that metaphor and reality therapy can increase the efficiency of counseling process and effective in increasing self-esteem. The results of the study strengthen the theoretical foundation that metaphor can independently be applied as a technique to intervene in low self-esteem.

\section{CONCLUSION}

Based on the result and the discussion above, it can be concluded that the pesantrenbased metaphor can increase the self-esteem of students. This conclusion is indicated by the increase in self-esteem score after intervention in the experimental group. The benefits generated by the metaphor also greatly depend on the suitability of its content and its type with the population or individual being intervened. For santri population, the pesantren-based metaphor is something familiar to them. It is very useful to apply it as a counseling technique to increase selfesteem.

\section{REFERENCES}

[1] Adhi, R. B. H. (2009). Hubungan antara self-esteem dengan penyalahgunaan narkotika dan obat-obatan berbahaya pada siswa SMK Negeri 2 Malang (Undergraduate Minithesis, Universitas Negeri Malang).

[2] Arista, D. (2006). Hubungan antara selfesteem dengan perilaku seksual pranikah pada siswa kelas XI SMU Widya Gama Malang (Undergraduate Minithesis, Universitas Negeri Malang).

[3] Arnett, J. J. (2014). Adolescence and emerging adulthood. Boston, MA: Pearson.
[4] Baldwin, S. A., \& Hoffmann, J. P. (2002). The dynamics of self-esteem: A growthcurve analysis. Journal of Youth and Adolescence, 31, 2, pp. 101-113.

[5] Burns, G. W. (2005). 101 healing stories for kids and teens: Using metaphors in therapy. John Wiley \& Sons.

[6] Burns, G. W. (Ed.). (2007). Healing with stories: Your casebook collection for using therapeutic metaphors. John Wiley \& Sons.

[7] Chesley, G. L., Gillett, D. A., \& Wagner, W. G. (2008). Verbal and nonverbal metaphor with children in counseling. Journal of Counseling \& Development, 86, 4, pp. 399-411.

[8] Conte, C. (2009). Advanced techniques for counseling and psychotherapy. Springer Publishing Company.

[9] Coopersmith, S. (1967). The antecedents of self-esteem. Consulting Psychologists Pr.

[10]Creswell, J. W. (2009). Research design: Qualitative, quantitative, and mixed methods approaches. Sage publications.

[11] Finkenauer, C., Engels, R. C. M. E., Meeus, W., \& Oosterwegel, A. (2002). Self and identity in early adolescence. Understanding early adolescent self and identity: Applications and interventions, 25-56.

[12]Horton, L. (1996). The Effects of Bibliotherapy on Self-Esteem (Graduate Thesis, Eastern Illionis University).

[13]Ivey, A. E., Ivey, M. B., \& Zalaquett, C. P. (2010). Intentional interviewing and counseling: Facilitating client development in a multicultural society. Nelson Education.

[14]Kopp, R. R. (1998). Early recollections in Adlerian and metaphor therapy. Individual Psychology, 54, 4, pp. 480-486.

[15]Kopp, R. R. 2007. An Empty Sadness: Exploring and Transforming ClientGenerated Metaphor. Dalam Geogre W. Burns (Ed.), Healing with Stories: Your Casebook Collection for Using Therapeutic Metaphors (p. 30-43). John Wiley \& Sons Inc.

[16]Lawrence, D. (2006). Enhancing selfesteem in the classroom. Pine Forge Press.

[17]Lyddon, W. J., Clay, A. L., \& Sparks, C. L. (2001). Metaphor and change in counseling. Journal of Counseling \& Development, 79, 3, pp. 269-274.

[18] Mruk, C. J. (2006). Self-esteem research, theory, and practice: Toward a positive 
psychology of self-esteem. Springer Publishing Company.

[19] Plummer, D. (2005). Helping adolescents and adults to build self-esteem: A photocopiable resource book. Jessica Kingsley Publishers.

[20] Powell, M. L., Newgent, R. A., \& Lee, S. M. (2006). Group cinematherapy: Using metaphor to enhance adolescent selfesteem. The arts in psychotherapy, 33, 3, pp. 247-253.

[21] Puspitasari, M. 2007. Hubungan antara self-esteem, kecerdasan emosional, dan motivasi berprestasi dengan prestasi belajar siswa kelas akselerasi di SMA Negeri 1 Blitar (Undergraduate Minithesis, Universitas Negeri Malang).

[22]Rahman, D. H. (2010). Aspirasi dan makna karier santri kelas XII Sekolah Menengah Tingkat Atas di Pondok Pesantren Nurul Jadid Paiton Probolinggo (Undergraduate Minithesis, Universitas Negeri Malang).

[23] Rahman, D. H. (2013). Keefektifan teknik metafora dalam bingkai konseling realitas untuk meningkatkan harga diri siswa SMA (Graduate Thesis, Universitas Negeri Malang).
[24]Robins, R. W., \& Trzesniewski, K. H. (2005). Self-esteem development across the lifespan. Current directions in psychological science, 14, 3, pp. 158-162.

[25] Santrock, J. W. (2011). Life-span development. McGraw-Hill.

[26] Seligman, L. (2006). Theories of counseling and psychoterapy: systems, strategies, and skills. Pearson Merril Prentice.

[27] Smit, G. (2007). Trekking to HappinessNo Sherpa Required: A Utilization Approach to Transcending an Abusive Relationship. Dalam Geogre W. Burns (Ed.), Healing with Stories: Your Casebook Collection for Using Therapeutic Metaphors (p. 89-99). John Wiley \& Sons Inc.

[28] Syahbita, A. K. (2009). Hubungan antara penyesuaian sosial siswa kelas X SMA Negeri Kunir Kabupaten Lumajang (Undergraduate Minithesis, Universitas Negeri Malang).

[29] Utami, E. M. L. 2009. Hubungan antara self-esteem dan perilaku agresi siswa yang berada pada rentang usia remaja awal di SMK Penerbangan Angkasa Singosari (Undergraduate Minithesis, Universitas Negeri 